\title{
PVP-NiB amorphous catalyst for selective hydrogenation of phenol and its derivatives
}

\author{
Qinsheng Zhang a , Haifeng Li a , Ping Gao ${ }^{\text {b,\#, Lailai Wang a,* }}$ \\ a State Key Laboratory for Oxo Synthesis and Selective Oxidation, Lanzhou Institute of Chemical Physics, Chinese Academy of Sciences, Lanzhou 730000, \\ Gansu, China \\ ${ }^{\mathrm{b}}$ State Key Laboratory of Solid Lubrication, Lanzhou Institute of Chemical Physics, Chinese Academy of Sciences, Lanzhou 730000, Gansu, China
}

\section{A R T I C L E I N F O}

Article history:

Received 25 June 2014

Accepted 24 July 2014

Published 20 November 2014

\section{Keywords:}

Nickel

Phenol

Catalytic hydrogenation

Amorphous catalyst

\begin{abstract}
A B S T R A C T
PVP-NiB amorphous catalysts were prepared by the chemical reduction of nickel chloride with sodium borohydride, and characterized by infrared, X-ray diffraction, transmission election microscopy, and inductively coupled plasma. The relationship between the catalytic activity and nature of the active sites was discussed. PVP is a protective agent for preparing PVP-stabilized NiB catalysts, which improved the dispersion of the catalyst and stabilized its amorphous structure. The catalysis of phenol and its derivatives was evaluated in the aqueous phase. $99.9 \%$ conversion of phenol and $99.9 \%$ selectivity to cyclohexanol were obtained at $30^{\circ} \mathrm{C}$ and $0.2 \mathrm{MPa} \mathrm{H}_{2}$ after $18 \mathrm{~h}$ over PVP-NiB. The generality of the PVP-NiB catalyst for this reaction was demonstrated by the selective hydrogenation of other phenol derivatives, which showed that the PVP-NiB catalyst was selective for the formation of cyclohexanol.
\end{abstract}

(C) 2014, Dalian Institute of Chemical Physics, Chinese Academy of Sciences. Published by Elsevier B.V. All rights reserved.
Phenol is a byproduct of the petrochemical industry and can cause much damage to the environment. The hydrogenation of phenol is of commercial and environmental significance because the cyclohexanone and cyclohexanol produced are the intermediates for caprolactame and adipic acid used to manufacture nylon 6 and nylon 66, respectively. Cyclohexanone and cyclohexanol are also important intermediates for medicine, dyes and other chemicals. Therefore, the hydrogenation of phenol for the synthesis of cyclohexanone and cyclohexanol is an important chemical process that has been extensively studied [1-3].

Traditionally, the hydrogenation of phenol has been carried out in the gas phase at $120-300{ }^{\circ} \mathrm{C}$ over supported Pd catalysts. However, high temperatures cause catalyst deactivation due to coking during the reaction. The products from the hydrogenation of phenol are highly dependent on the properties of the support [4]. Liquid phase hydrogenation of phenol saves cost and energy because the reaction can be performed at relatively low temperatures and pressure. Many researchers have contributed to this area, and a number of catalysts have been screened. However, important drawbacks of liquid phase hydrogenation are the use of more sophisticated conditions (supercritical $\mathrm{CO}_{2}$ as solvent which requires high $\mathrm{H}_{2}$ and $\mathrm{CO}_{2}$ pressures > 7.0 MPa) and need of a cocatalyst [5-9]. Recently, Wang and co-workers achieved both excellent conversion and selectivity in the hydrogenation of phenol in an aqueous media by using a heterogeneous catalyst. A conversion and selectivity higher than $96 \%$ was obtained. Nevertheless, the preparation

\footnotetext{
* Corresponding author. Tel: +86-931-4968161; Fax: +86-931-4968129; E-mail: wll@licp.cas.cn

\# Corresponding author. Tel: +86-931-4968177; Fax: +86-931-4968163; E-mail: gaoping@licp.cas.cn

This work was supported by the National Natural Science Foundation of China (21174115) and the Youth Foundation of Gansu Province (1308RJYA036).

DOI: 10.1016/S1872-2067(14)60203-5 | http://www.sciencedirect.com/science/journal/18722067 | Chin. J. Catal., Vol. 35, No. 11, November 2014
} 
of the mpg- $\mathrm{C}_{3} \mathrm{~N}_{4}$ support involved the use of aqueous ammonium bifluoride $\left(\mathrm{NH}_{4} \mathrm{HF}_{2}\right)$ and/or hydrogen fluoride (HF) which are hazardous and not environmentally friendly [10]. Rode et al. [11] used supercritical $\mathrm{CO}_{2}$ as a solvent, which requires high $\mathrm{H}_{2}$ and $\mathrm{CO}_{2}$ pressures > 7.0 $\mathrm{MPa}$. Liu et al. [12] achieved both excellent conversion and selectivity in the hydrogenation of phenol using a dual-supported Pd Lewis acid catalyst. However, the catalyst contains Lewis acids such as $\mathrm{AlCl}_{3}$, phosphotungstic acid, which imposes severe limitations on their use in hydrogenation applications in general and adds a chemical sensitivity that restricts substrates, purity, and reaction conditions. Therefore, the design and preparation of a novel catalyst with high activity and selectivity is still a challenge.

As is well known, nanoscale amorphous alloy catalysts with long range disorder and short range order usually exhibit higher activity and better selectivity in hydrogenation. Their unique structure and high concentration of coordinatively unsaturated sites lead to catalytic activity and selectivity superior to those of their crystalline counterparts $[13,14]$. For example, Li et al. $[15,16]$ synthesized a novel mesoporous Ce-doped Pd catalyst with a hollow chamber. This catalyst exhibited a higher activity and selectivity to cyclohexanone in the liquid phase hydrogenation of phenol. The hydrogenation of bio-oil model compounds was carried out using Ni-B amorphous catalysts. The results showed that the conversion of model compounds (acetone, furfural and phenol) and the selectivity of saturated alcohols reached $99.9 \%$ and $95 \%$ at $110{ }^{\circ} \mathrm{C}, 4 \mathrm{MPa} \mathrm{H}_{2}$ for $4 \mathrm{~h}$ [17]. Poly( $N$-vinyl-2-pyrrolidone) (PVP) is a water-soluble polymer, and is applied as a protective agent for preparing nanoscale catalysts [18]. In this paper, we present a new method for the synthesis of cyclohexanol by the aqueous phase selective hydrogenation of phenol using a PVP-NiB amorphous catalyst for the first time.

The PVP-NiB amorphous catalyst was prepared by the reduction of nickel chloride with $\mathrm{NaBH}_{4}$ [18]. The water-soluble polymer served as both a protective reagent and support. Before the reduction, PVP $(0.3 \mathrm{~g}, 0.027 \mathrm{~mol})$ and nickel chloride $(2.0 \mathrm{~g}, 0.008 \mathrm{~mol})$ were dissolved in methanol $(20 \mathrm{~mL})$ at $80{ }^{\circ} \mathrm{C}$ for $3 \mathrm{~h} . \mathrm{NaBH}_{4}(1.0 \mathrm{~g}$ ) was slowly added to the solution. The resulting black precipitate was separated with a high speed centrifuge, and thoroughly washed three times with distilled water. The fresh wet catalyst was dried at $45^{\circ} \mathrm{C}$ overnight in a vacuum oven. In a similar way, other catalysts of the different molar ratios of Ni to PVP monomer were synthesized, respectively. The PVP-NiB amorphous catalysts were characterized by their infrared spectra (IR), X-ray diffraction (XRD), transmission electron microscopy (TEM), X-ray photoelectron spectra (XPS) and inductively coupled plasma analysis (ICP).

A typical procedure for the hydrogenation of phenol was as follows. PVP-NiB (0.5 g), phenol (0.1 g) and water (6 mL) were placed in a $20 \mathrm{~mL}$ reactor. The reactor system was purged with $\mathrm{N}_{2}$ three times followed by $\mathrm{H}_{2}$ three times. The reaction was started under $0.2 \mathrm{MPa} \mathrm{H}_{2}$. The reaction mixture was stirred vigorously at the reaction temperature. The products were separated from the water. First, the catalyst was removed from the liquid by filtration. Then the organic phase was extracted and analyzed by a GC 112A equipped with a FID detector and an SE-54 column (30 $\mathrm{m} \times 0.25 \mathrm{~mm} \times 0.25 \mu \mathrm{m}$ film thickness), column temperature $140{ }^{\circ} \mathrm{C}$, detector $230{ }^{\circ} \mathrm{C}$, sample injector $220^{\circ} \mathrm{C}$.

The IR spectra of PVP and the PVP-NiB amorphous catalyst were recorded using a Nicolet iS10 FTIR spectrometer. The results are shown in Fig. 1. It was found that the peak positions from 3000 to $400 \mathrm{~cm}^{-1}$ and the intensity of the absorption peak were changed. This may be due to the coordinative bond between the oxygen atom and nitrogen atom of the PVP molecule with the surficial Ni atom [19]. For example, there were absorption intensity weakening and a blue-shift of the $\mathrm{C}=0$ stretch vibrational band $\left(1662 \mathrm{~cm}^{-1}\right)$ for PVP-NiB compared with pure PVP [20]. In addition, the peak was broadened and there were blue shifts of the bending vibration at $1463 \mathrm{~cm}^{-1}$ $\left(-\mathrm{CH}_{2}-\right)$ and stretch vibrational band at $1291 \mathrm{~cm}^{-1}(-\mathrm{C}-\mathrm{C}-)$. These were due to the coordination of the lone pair electrons of $\mathrm{N}$ and $\mathrm{O}$ with the empty orbitals of $\mathrm{Ni}$ [21]. The results showed that PVP molecules existed on the surface of the catalyst, and the $\mathrm{N}$ and $\mathrm{O}$ of PVP coordinated with the metal Ni atom.

Selected PVP-NiB catalysts were synthesized with the molar ratio of Ni to PVP monomer of 8:27. According to the ICP analysis, the compositions of the $\mathrm{Ni}$ and $\mathrm{B}$ were $47.9 \%$ and $11.4 \%$ (weight percent), respectively and the ratio of $\mathrm{Ni}$ to $\mathrm{B}$ (molar/molar) was 1:1.4. Figure 2 shows the XRD patterns of the PVP-NiB catalysts. As can be seen, catalysts with different proportions of $n(\mathrm{Ni}): n(\mathrm{PVP})$ have similar XRD patterns. Only one broad diffraction peak was observed at around $45^{\circ}$, which is indicative of a typical Ni-B amorphous structure [22]. When PVP-NiB $(n(\mathrm{Ni}): n(\mathrm{PVP})=8: 27)$ was applied in the hydrogenation of phenol at $30^{\circ} \mathrm{C}, 0.2 \mathrm{MPa} \mathrm{H}_{2}$, and $18 \mathrm{~h}$, one broad diffraction peak was observed at around $45^{\circ}$ in the obtained sampe, the same as the fresh one. The results showed the high stability of the catalyst, which can be reused.

Figure 3 shows the TEM micrographs and corresponding particle size distribution of the PVP-NiB samples. The images revealed well dispersed particles with a mean size of $3 \mathrm{~nm}$, a narrow size distribution, and no aggregation. The corresponding mean particle diameters were measured and calculated by counting 190 particles from the enlarged photographs.

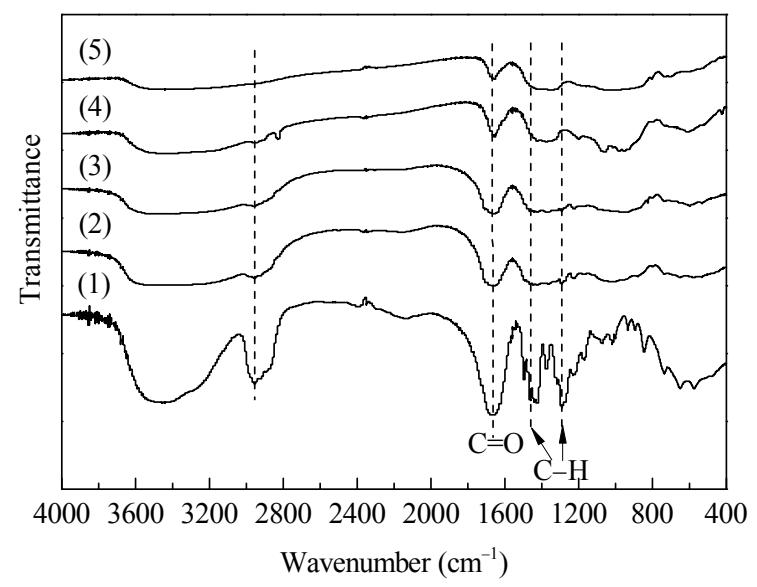

Fig. 1. IR spectra of PVP (1) and PVP-NiB catalyst with different molar ratios of Ni:PVP. (2) 2:27; (3) 4:27; (4) 8:27; (5) 16:27. 


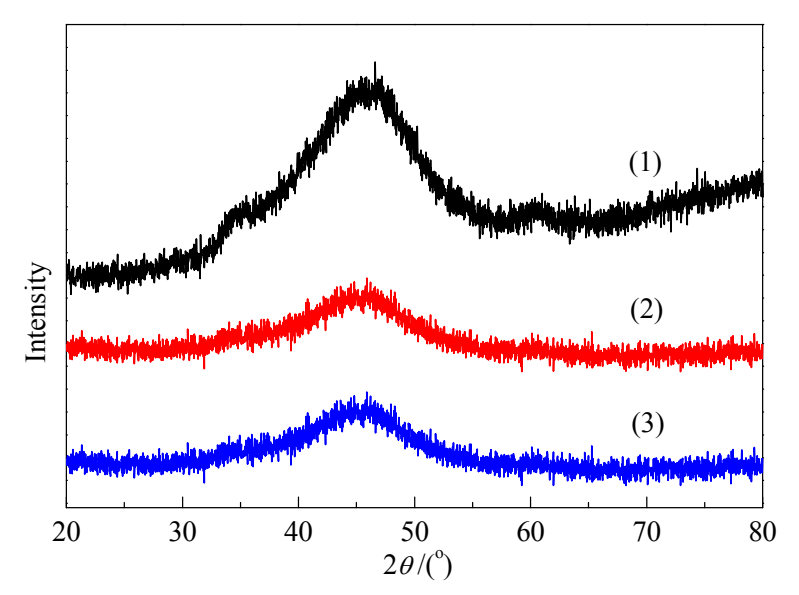

Fig. 2. XRD patterns of PVP-NiB with different molar ratios of Ni:PVP. (1) 8:27; (2) Used (1); (3) 16:27.
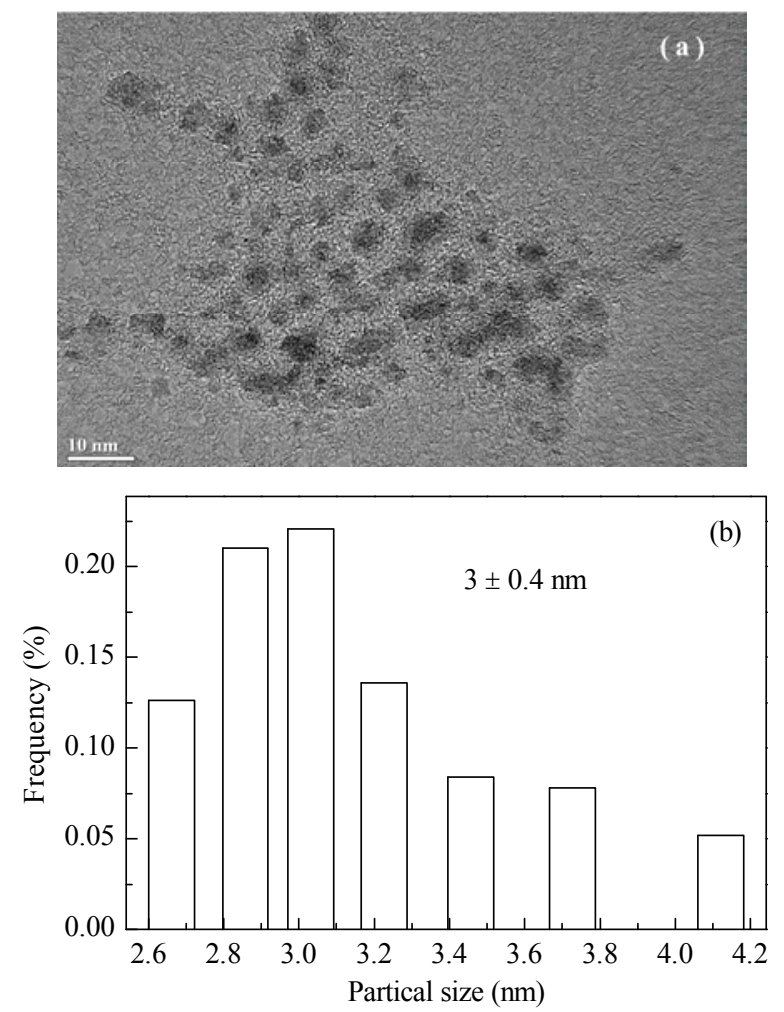

Fig. 3. TEM micrograph (a) and corresponding particle size distribution (b) of PVP-NiB with molar ratio of Ni:PVP = 8:27.

The PVP-NiB amorphous catalysts were characterized by XPS. The results are shown in Fig. 4. From the energy levels of $\mathrm{Ni} 2 p_{3 / 2}$ of the PVP-NiB samples, there were Ni atoms in the PVP-NiB samples in the metallic Ni state with the binding energy (BE) of $852.1 \mathrm{eV}$, and $\mathrm{Ni}$ atoms in the oxide state with the $\mathrm{BE}$ of $855.3 \mathrm{eV}$. From the energy levels of $\mathrm{B} 1 \mathrm{~s}$, the boron alloyed state (BE, $188.6 \mathrm{eV}$ ) and the boron oxide state (BE, 191.7 $\mathrm{eV}$ ) were detected on the PVP-NiB samples. One can conclude that the presence of these species was not due to the surface oxidation of the Ni-B amorphous alloy. Perhaps they resulted from the hydrolysis of $\mathrm{NaBH}_{4}$, since the reduction of nickel ions by $\mathrm{NaBH}_{4}$ was performed in solution [22]. We think that the
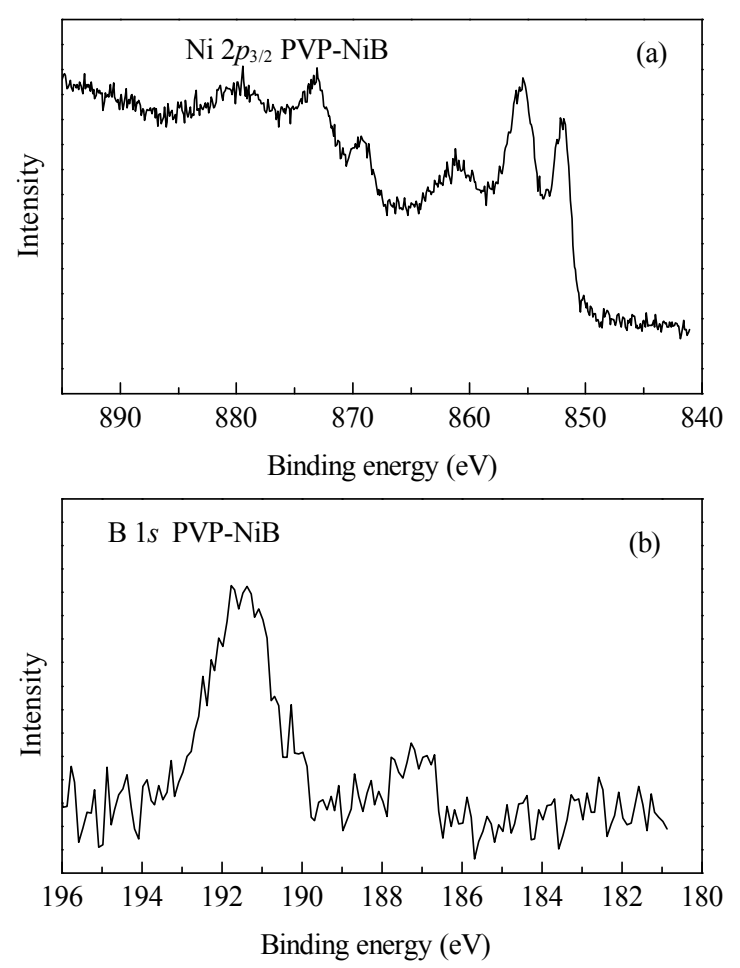

Fig. 4. XPS spectra of Ni $2 p$ (a) and B ls (b) of PVP-NiB sample.

boron on the catalytic surface can be oxidized, but it was not confirmed. The BE of boron in the alloyed state $(188.6 \mathrm{eV})$ displayed a positive shift of $1.4 \mathrm{eV}$ with respect to the $\mathrm{BE}$ of amorphous boron (187.2 eV), and the BE of Ni decreased by 0.7 $\mathrm{eV}$. This suggested that partial electron transfer occurred from elemental $\mathrm{B}$ to $\mathrm{Ni}$, making the metal $\mathrm{Ni}$ a rich electronic state, and $\mathrm{B}$ a deficient electronic state [23].

Table 1 presents the results of phenol hydrogenation under different conditions over the PVP-NiB catalysts. The activity and selectivity of the reaction using four kinds of catalysts synthesized with the molar ratios of Ni to PVP monomer (molar /molar) of 2:27, 4:27, 8:27, 16:27 were evaluated. The conversion of phenol was $43.2 \%, 66.1 \%, 86.2 \%, 83.1 \%$ at $30{ }^{\circ} \mathrm{C}, 0.2$ MPa for $12 \mathrm{~h}$ with the cyclohexanol selectivity above $99.9 \%$ (Table 1, entries 1-4), when the $n(\mathrm{Ni}): n(\mathrm{PVP})$ ratios increased. The conversion of phenol was gradually increased when the ratioes of Ni to PVP monomer (molar/molar) were from 2:27 to 8:27. But with more increase in the amount of Ni to PVP monomer, the conversion began to decline. We selected catalyst PVP-NiB synthesized with the ratio of $\mathrm{Ni}$ to PVP monomer (molar/molar) of 8:27, and investigated the effect of reaction time, dosage of catalyst, and temperature on the activity and selectivity of the reaction. With increasing dosage of the catalyst, the conversion of phenol was obviously elevated (entries 5,6 , and 7). When the dosage of the catalyst was $0.25 \mathrm{~g}$, the conversion of phenol reached $99.9 \%$ at the elevated temperature and $3 \mathrm{MPa} \mathrm{H}_{2}$ in $4 \mathrm{~h}$ (entry 8). On prolonging the reaction time to 18,22 , and $60 \mathrm{~h}$, the conversion of phenol and the selectivity of cyclohexanol still exceeded 99.9\% (entries 9-11). The reaction was accelerated at higher temperature. For example, a high conversion of $99.9 \%$ in $12 \mathrm{~h}$ was obtained at $60{ }^{\circ} \mathrm{C}$ 
Table 1

Hydrogenation of phenol using PVP-NiB catalyst in water under various conditions.

\begin{tabular}{|c|c|c|c|c|c|c|c|}
\hline \multirow{2}{*}{ Entry } & \multirow{2}{*}{$n(\mathrm{Ni}): n(\mathrm{PVP})$} & \multirow{2}{*}{$P_{\mathrm{H} 2}(\mathrm{MPa})$} & \multirow{2}{*}{$T\left({ }^{\circ} \mathrm{C}\right)$} & \multirow{2}{*}{$t(\mathrm{~h})$} & \multirow{2}{*}{ Conversion (\%) } & \multicolumn{2}{|c|}{ Selectivity (\%) } \\
\hline & & & & & & $\mathrm{C}-\mathrm{OH}$ & $\mathrm{C}=\mathrm{O}$ \\
\hline 1 & $2: 27$ & 0.2 & 30 & 12 & 43.2 & $>99.9$ & 0 \\
\hline 2 & $4: 27$ & 0.2 & 30 & 12 & 66.1 & $>99.9$ & 0 \\
\hline 3 & $8: 27$ & 0.2 & 30 & 12 & 86.2 & $>99.9$ & 0 \\
\hline 4 & $16: 27$ & 0.2 & 30 & 12 & 83.1 & $>99.9$ & 0 \\
\hline $5^{a}$ & $8: 27$ & 0.2 & 30 & 18 & 40.2 & $>99.9$ & 0 \\
\hline $6^{b}$ & $8: 27$ & 0.2 & 30 & 18 & 60.1 & $>99.9$ & 0 \\
\hline $7^{c}$ & $8: 27$ & 0.2 & 30 & 18 & 76.5 & $>99.9$ & 0 \\
\hline $8^{d}$ & $8: 27$ & 3 & 100 & 4 & $>99.9$ & $>99.9$ & 0 \\
\hline 9 & $8: 27$ & 0.2 & 30 & 18 & $>99.9$ & $>99.9$ & 0 \\
\hline 10 & $8: 27$ & 0.2 & 30 & 22 & $>99.9$ & $>99.9$ & 0 \\
\hline 11 & $8: 27$ & 0.2 & 30 & 60 & $>99.9$ & $>99.9$ & 0 \\
\hline 12 & $8: 27$ & 0.2 & 60 & 12 & $>99.9$ & $>99.9$ & 0 \\
\hline 13 & $8: 27$ & 0.2 & 100 & 10 & $>99.9$ & $>99.9$ & 0 \\
\hline 14 & $8: 27$ & 1.0 & 100 & 10 & $>99.9$ & $>99.9$ & 0 \\
\hline 15 & $8: 27$ & 2.0 & 100 & 8 & $>99.9$ & $>99.9$ & 0 \\
\hline
\end{tabular}

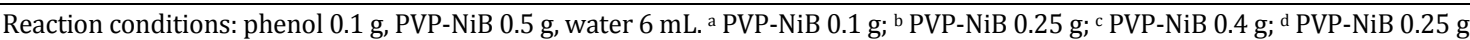

(entry 12), at $100{ }^{\circ} \mathrm{C}$ in $10 \mathrm{~h}, 99.9 \%$ conversion could be reached (entry 13). The conversion and selectivity of up to $99.9 \%$ were achieved by increasing the hydrogen pressure to 1.0 and $2.0 \mathrm{MPa}$ at $100{ }^{\circ} \mathrm{C}$ for 10 and $8 \mathrm{~h}$ (entries 14 and 15). Therefore, the reaction temperature had a considerable effect on the conversion of phenol and selectivity of the reaction. The product of the hydrogenation of phenol was cyclohexanol over the PVP-NiB amorphous catalyst at a lower temperature and pressure. It was found that the selectivity did not change on extending the reaction time. We increased the reaction time to $60 \mathrm{~h}$, and the selectivity to cyclohexanol did not decrease.

The PVP-NiB amorphous catalyst exhibited high activity and selectivity to cyclohexanol in the liquid phase phenol hydrogenation. These results are related to the morphology of the catalyst. TEM image revealed well dispersed particles with a mean size of $3 \mathrm{~nm}$, a narrow size distribution, and no aggregation. XPS analysis indicated that partial electron transfer occurred from elemental B to Ni metal, making the metal $\mathrm{Ni}$ a rich electronic state, and B a deficient electronic state. The electronic effect greatly promoted the hydrogenation activity of the catalysts [23]. XRD results of samples indicated the catalyst had an amorphous structure. The amorphous alloy catalysts with long range disorder and short range order usually exhibit higher activity and better selectivity during the hydrogenation. A high concentration of coordinatively unsaturated sites led to catalytic activity and selectivity superior to other catalysts in the hydrogenation of phenol [24].

To illustrate the general applicability of PVP-NiB, other phenol derivatives were tested. Table 2 shows the results of the hydrogenation. As can be seen, the conversions of the phenol derivatives were lower than phenol. The selectivity to cyclohexanol was similar to the phenol. The conversion of $p$-cresol and $o$-cresol were $88.3 \%$ and $90.1 \%$ at $120^{\circ} \mathrm{C}, 1 \mathrm{MPa} \mathrm{H}_{2}$ and 16 h. However, the conversion of $p$-tert-butylphenol and guaiacol were only $20.1 \%$ and $20.0 \%$ at $120^{\circ} \mathrm{C}, 2 \mathrm{MPa} \mathrm{H}_{2}$ for $24 \mathrm{~h}$. When the substitution of the aromatic ring was varied, the conversion and selectivity of the reaction were different. This may be due to the lower aqueous solubility of the phenol derivatives com-
Table 2

Hydrogenation of phenol derivatives using PVP-NiB catalyst in water under the optimization conditions.

\begin{tabular}{|c|c|c|c|c|c|}
\hline Substrate & $\begin{array}{c}P_{\mathrm{H} 2} \\
(\mathrm{MPa}) \\
\end{array}$ & $\begin{array}{l}\text { Time } \\
\text { (h) }\end{array}$ & $\begin{array}{c}\text { Conversion } \\
(\%)\end{array}$ & Product & $\begin{array}{c}\text { Selectivity } \\
(\%)\end{array}$ \\
\hline & 1 & 16 & 88.3 & & $>99.9$ \\
\hline & 1 & 16 & 90.1 & & $>99.9$ \\
\hline & 2 & 24 & 20.1 & & $>99.9$ \\
\hline & 2 & 24 & 20.0 & & $>99.9$ \\
\hline
\end{tabular}

pared with phenol [7].

In conclusion, PVP-NiB catalysts were prepared by the chemical reduction method and successfully applied in the hydrogenation of phenol and its derivatives. PVP-NiB exhibited high activity for the hydrogenation of phenol to the corresponding alcohols with water as solvent under mild conditions. The reaction was accelerated at higher temperature. PVP-NiB showed low activity and high selectivity to alcohols for the hydrogenation of $p$-cresol and $o$-cresol. The selectivity to the corresponding alcohols was up to $99.9 \%$. However, the conversion was lower in the hydrogenation of $p$-tert-butylphenol and guaiacol. How to improve the catalytic activity for the hydrogenation of phenol derivatives, and the reusability of the PVP-NiB catalysts will be the subject of future studies.

\section{References}

[1] Chary K V R, Naresh D, Vishwanathan V, Sadakane M, Ueda W. Catal Commun, 2007, 8: 471

[2] Shore S G, Ding E, Park C, Keane M A. Catal Commun, 2002, 3: 77 


\title{
Graphical Abstract
}

Chin. J. Catal., 2014, 35: 1793-1799 doi: 10.1016/S1872-2067(14)60203-5

PVP-NiB amorphous catalyst for selective hydrogenation of phenol and its derivatives

Qinsheng Zhang, Haifeng Li, Ping Gao*, Lailai Wang* Lanzhou Institute of Chemical Physics, Chinese Academy of Sciences

The selective hydrogenation of phenol and its derivatives to saturated alcohols in the aqueous phase was achieved using water-soluble PVP-NiB nanoparticles under mild conditions.

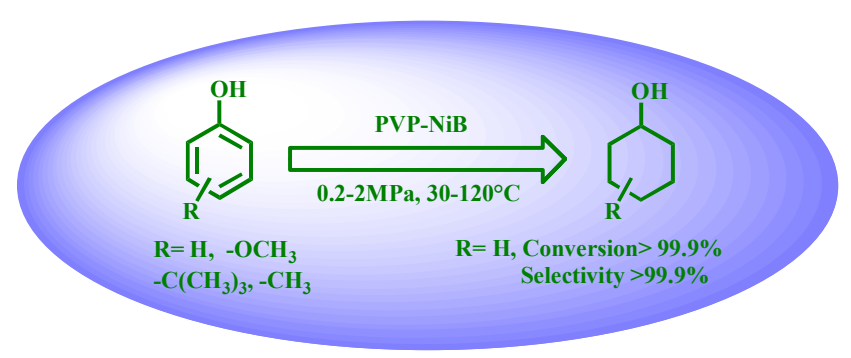

[3] Mahata N, Vishwanathan V. Ind J Chem A, 1998, 37: 652

[4] Scirè S, Minicò S, Crisafulli C. Appl Catal A, 2002, 235, 21

[5] Chen A B, Zhao G Y, Chen J Z, Chen L M, Yu Y F. RSC Adv, 2013, 3: 4171

[6] Cheng H Y, Liu R X, Wang Q, Wu C Y, Yu Y C, Zhao F Y. New J Chem, 2012, 36: 1085

[7] Xiang Y Z, Ma L, Lu C S, Zhang Q F, Li X N. Green Chem, 2008, 10: 939

[8] Park H W, Kim J K, Hong U G, Lee Y J, Song J H, Song I K. Appl Catal A, 2013, 453: 287

[9] Yu Y X, Xu Y, Wang T J, Ma L L, Zhang Q Zhang X H, Zhang X. J Fuel Chem Technol (于玉肖, 徐䒯, 王铁军, 马隆龙, 张琦, 张兴华, 张 雪. 燃料化学学报), 2013, 41: 443

[10] Wang Y, Yao J, Li H R, Su D S, Antonietti M. J Am Chem Soc, 2011, 133: 2362

[11] Rode C V, Joshi U D, Sato O, Shirai M. Chem Commun, 2003: 1960

[12] Liu H Z, Jiang T, Han B X, Liang S G, Zhou Y X. Science, 2009, 326: 1250
[13] Wang W Y, Yang Y Q, Luo H, Peng H Z, He B, Liu W Y. Catal Commun, 2011, 12: 1275

[14] Li H, Liu J, Xie S H, Qiao M H, Dai W L, Li H X. J Catal, 2008, 259: 104

[15] Zhuang L, Li H X, Dai W L, Qiao M H. Chem Lett, 2003, 32: 1072

[16] Li H, Liu J L, Li H X. Mater Lett, 2008, 62: 297

[17] Yu Y X, Zhang X H, Wang T J, Xu Y, Ma L L, Zhang Q, Zhang L M. Chem J Chin Univ, 2013, 34: 2178

[18] Liaw B J, Chiang S J, Tsai C H, Chen Y Z. Appl Catal A, 2005, 284: 239

[19] Zhang Z T, Zhao B, Hu L M. J Solid State Chem, 1996, 121: 105

[20] Koo C M, Ham H T, Choi M H, Kim S O, Chung I J. Polymer, 2003, 44: 681

[21] Roucoux A, Schulz J, Patin H. Chem Rev, 2002, 102: 3757

[22] Dai W L, Li H X, Cao Y, Qiao M H, Fan K N, Deng J F. Langmuir, 2002, 18: 9605

[23] Chen Y Z, Liaw B J, Chiang S J. Appl Catal A, 2005, 284: 97

[24] Deng J F, Li H, Wang W. Catal Today, 1999, 51: 113

\section{PVP-NiB非晶态催化剂的制备和催化苯酚及其衍生物加氢反应性能}

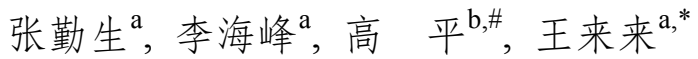 \\ a 中国科学院兰州化学物理研究所, 羰基合成与选择氧化国家重点实验室, 甘肃兰州 730000 \\ $\mathrm{b}$ 中国科学院兰州化学物理研究所, 固体润滑国家重点实验室, 甘肃兰州 730000
}

摘要: 以聚乙烯吡咯烷酮(PVP)为稳定剂, 采用化学还原法制备了PVP-NiB非晶态催化剂, 通过红外光谱、X射线衍射、透射电子 显微镜和电感耦合等离子体光谱对催化剂进行了表征. 结果表明, PVP不仅能够提高NiB纳米颗粒的分散度, 而且对其起到稳定 作用; 将该催化剂首次应用于苯酚及其衍生物的催化加氢反应, 在水相体系中, $30^{\circ} \mathrm{C}$ 及氢气压力 $0.2 \mathrm{MPa}$ 时, 苯酚的转化率和环己 醇的选择性都能够达到 $99.9 \%$; 酚类衍生物加氢反应结果发现, 该催化剂有利于环已醇类物质的生成, 初步考察了 PVP-NiB非晶 态催化剂的构效关系.

关键词: 镍; 苯酚; 催化加氢; 非晶态催化剂

收稿日期: 2014-06-25. 接受日期: 2014-07-24. 出版日期: 2014-11-20.

*通讯联系人. 电话: (0931)4968161; 传真: (0931)4968129; 电子信箱: wll@licp.cas.cn

通讯联系人. 电话: (0931)4968177; 传真: (0931)4968163; 电子信箱: gaoping@licp.cas.cn

基金来源：国家自然科学基金(21174115); 甘肃省青年基金(1308RJYA036).

本文的英文电子版由Elsevier出版社在ScienceDirect上出版(http://www.sciencedirect.com/science/journal/18722067).

苯酚是石油化工的副产物, 也是环境有害物质, 因 此, 苯酚催化加氢制备环己酮和环己醇在近年来引起广 泛关注 $^{[1-3]}$. 而环己酮和环已醇(KA 油) 是合成己内酰胺
和已二酸的重要原料, 后者分别是合成功能高分子纤维 尼龙6及尼龙66的单体; 环己酮和环己醇也是医药、染料 等精细化学品的重要中间体. 传统的苯酚加氢以负载 $\mathrm{Pd}$ 
为催化剂, 在高温、气相下进行, 容易形成积炭, 导致催化 剂失活, 且加氢产物对载体有一定的依赖性 ${ }^{[4]}$. 液相加氢 可在较低的温度和压力下进行, 降低成本与节省能源, 但 大多数情况下反应条件苛刻, 如在超临界 $\mathrm{CO}_{2}$ 中进行, 或 需要加入助催化剂 ${ }^{[5-9]}$. Wang 等 ${ }^{[10]}$ 道采用 $\mathrm{Pd} @ m p g-\mathrm{C}_{3} \mathrm{~N}_{4}$ 催化剂, 苯酚转化率和环已酮选择性 $>96 \%$, 但催化剂合 成过程复杂, 且会产生强腐蚀性物质(HF); Rode 等 ${ }^{[11]}$ 在 超临界 $\mathrm{CO}_{2}$ 中进行苯酚加氢反应, $\mathrm{H}_{2}$ 和 $\mathrm{CO}_{2}$ 压力 $>7 \mathrm{MPa}$ 才可发生反应; Han等 ${ }^{[12]}$ 在苯酚加氢反应中加入助催化 剂如磷铇酸、 $\mathrm{AlCl}_{3}$, 反应活性和选择性增加, 但产物的分 离和纯化比较困难, 且受限于设备和反应条件. 因此, 高 活性和高选择性的催化剂仍然是苯酚及其衍生物加氢 合成环己醇需要解决的关键科学问题.

非晶态催化剂具有长程无序, 短程有序的独特结构, 其表面存在大量配位不饱和的活性位, 在加氢反应中表 现出较高活性 ${ }^{[13,14]}$. 李和兴等 ${ }^{[15,16]}$ 将Ce掺杂的Pd-B非晶 态催化剂应用于苯酚加氢合成环己酮, 催化剂显示高活 性、高选择性和高稳定性; 王铁军等 ${ }^{[17]}$ 利用 Ni-B(Ni/B摩 尔比为 $1: 0.365)$ 非晶态催化剂对生物油模型化合物苯 酚、糠醛、丙酮进行加氢反应研究, 在 $110^{\circ} \mathrm{C}, 4 \mathrm{MPa} 反$ 应 $4 \mathrm{~h}$, 转化率均达到 $99.9 \%$, 其相应醇类的选择性达到 $95 \%$ 以上. 聚乙烯吡咯烷酮(PVP)作为一种防止纳米粒 子团聚的水溶性有机高分子聚合物, 在负载型纳米粒子 的制备中经常用作保护剂 ${ }^{[18]}$. 而PVP-NiB非晶态催化剂 在苯酚加氢反应中的应用尚未见报道. 本文以 PVP为稳 定剂, 采用化学还原法制备PVP-NiB非晶态催化剂, 首次 将其应用于水中苯酚及其他衍生物催化加氢反应中.

PVP-NiB 非晶态催化剂通过化学还原法制备 ${ }^{[18]}$. 制 备过程如下: 向三颈烧瓶中加入 $\mathrm{NiCl}_{2} \cdot 6 \mathrm{H}_{2} \mathrm{O}(2.0 \mathrm{~g}, 8$ $\mathrm{mmol}), \mathrm{PVP}(0.3 \mathrm{~g}, 27 \mathrm{mmol})$ 和 $20 \mathrm{~mL}$ 甲醇, 于 $80^{\circ} \mathrm{C}$ 反应 $3 \mathrm{~h}$, 溶液呈绿色. 将 $1.0 \mathrm{~g} \mathrm{NaBH}_{4}$ 粉末分多次加入上述溶 液中, 溶液由绿色立即变为黑色, 伴有气体放出; 待加完 $\mathrm{NaBH}_{4}$ 后, 反应 $1 \mathrm{~h}$, 将黑色溶液离心分离, 用去离子水洗 涤3次, $45^{\circ} \mathrm{C}$ 下真空干燥过夜, 即得 PVP-NiB 非晶态合金 催化剂.

采用红外光谱(IR), X射线衍射仪(XRD), 和透射电 子显微镜(TEM)分析催化剂的结构和表面形貌, 表面电 子态则由 X射线光电子能谱(XPS)测定. 催化剂的组成和 负载量采用电感耦合等离子体光谱(ICP)测定.

苯酚及其衍生物加氢过程如下: 将 $0.5 \mathrm{~g}$ PVP-NiB 非 晶态催化剂、 $0.1 \mathrm{~g}$ 苯酚、 $6 \mathrm{~mL}$ 蒸馏水依次加到 $20 \mathrm{~mL}$ 高 压反应釜中, 封闭, 通入 $\mathrm{N}_{2}$ 置换 3 次, 再通入 $\mathrm{H}_{2}$ 置换 3 次后,
将 $\mathrm{H}_{2}$ 压力升至 $0.2 \mathrm{MPa}$, 开始摚拌, 加热至设定反应温度, 反应至设定时间. 反应结束后, 冷却至室温, 萃取分离有 机相和水相, 将有机相干燥. 采用气相色谱仪 GC112A分 析反应产物, 确定反应的转化率和产物的选择性, 色谱条 件为: 氢火焰检测器, SE-54毛细管柱 $(30 \mathrm{~m} \times 0.25 \mathrm{~mm} \times$ $0.25 \mu \mathrm{m}$ ), 柱温 $140^{\circ} \mathrm{C}$, 检测器 $230^{\circ} \mathrm{C}$, 进样口 $220^{\circ} \mathrm{C}$.

图1为 PVP及 $P V P-N i B$ 非晶态催化剂的IR谱. 可见随 着 $n(\mathrm{Ni}): n(\mathrm{PVP})$ 比的增加, 在 $3000-400 \mathrm{~cm}^{-1}$ 区域内的 IR 峰的位置和强度均发生明显变化. 这可能是由于PVP中 的 $\mathrm{N}, \mathrm{O}$ 原子与金属离子 $\mathrm{Ni}$ 形成配位键, 从而影响了 PVP-NiB非晶态催化剂中 PVP分子上某些官能团的IR 峰 ${ }^{[19]}$ : 如PVP-NiB非晶态催化剂中归属于 $\mathrm{PVP}$ 中 $\mathrm{C}=\mathrm{O}$ 伸 缩振动峰 $\left(1662 \mathrm{~cm}^{-1}\right)^{[20]}$ 明显减弱, 并发生小的蓝移, 这是 由于金属 $\mathrm{Ni}$ 与羰基氧配位, 削弱了 $\mathrm{C}=\mathrm{O}$ 所致; 催化剂在 1500-1200 $\mathrm{cm}^{-1}$ 区域的吸收峰相对于纯PVP变宽并发生 蓝移, 如 $\mathrm{CH}_{2}$ 的弯曲振动吸收峰 $\left(1463 \mathrm{~cm}^{-1}\right)$ 和 $\mathrm{C}-\mathrm{C}$ 单键伸 缩振动吸收峰 $\left(1291 \mathrm{~cm}^{-1}\right)$, 这是由于 $\mathrm{PVP}$ 分子中 $\mathrm{N}, \mathrm{O}$ 上的 孤对电子与 $\mathrm{Ni}$ 的空的 $d$ 轨道配位, 使 $\mathrm{C}=\mathrm{O}$ 与 $\mathrm{C}-\mathrm{N}$ 之间的耦 合作用增强所致 ${ }^{[21]}$. 由此可见, 在催化剂表面存在PVP分 子, $\mathrm{Ni}$ 原子与PVP分子之间存在配位作用, 而不仅仅是简 单的物理吸附.

对于 $n(\mathrm{Ni}): n(\mathrm{PVP})=8: 27$ 的PVP-NiB催化剂, ICP结果 显示其中 $\mathrm{Ni}$ 和B的含量分别为 $47.89 \%$ 和 $11.36 \%, \mathrm{Ni} / \mathrm{B}$ 摩 尔比为 1:1.4. 图 2 为各 PVP-NiB 非晶态合金催化剂的 XRD谱, 由图可见不同 $n(\mathrm{Ni}): n(\mathrm{PVP})$ 的催化剂谱相似, 均 在 $2 \theta=45^{\circ}$ 附近出现一个宽的非晶态合金的特征弥散峰, 表明所制催化剂均为非晶态结构, 与文献[18]报道的结 果一致. 对于使用后的催化剂, 其非晶态合金的特征弥 散峰基本不变, 说明该催化剂结构稳定, 可以重复使用.

图3为催化剂的TEM照片和粒径分布图,由图可见, 催化剂颗粒分散均匀, 无团聚现象, 平均粒径在 $3 \mathrm{~nm}$ 左 右,颗粒物周围灰色阴影是高分子稳定剂PVP.

图4为催化剂样品的XPS谱. 可以看出, 样品中的 $\mathrm{Ni}$ 以金属单质 $\mathrm{Ni}$ (结合能 $852.1 \mathrm{eV}$ ) 和氧化态 $\mathrm{Ni}$ (结合能 $855.3 \mathrm{eV}$ )两种形式存在, 氧化态 $\mathrm{Ni}$ 可能源于制备过程中 形成 $\mathrm{NiO}$ 和 $\mathrm{Ni}(\mathrm{OH})_{2}$ 副产物. 样品中的B也以单质(结合能 为 $188.6 \mathrm{eV}$ )和氧化态(结合能为 $191.7 \mathrm{eV}$ )形式存在. 研究 发现 ${ }^{[22]}, \mathrm{B}_{2} \mathrm{O}_{3}$ 并不是来自 Ni-B催化剂表面被氧化, 而是 在 $\mathrm{NaBH}_{4}$ 还原 $\mathrm{Ni}$ 物种过程中, 可能伴随着 $\mathrm{NaBH}_{4}$ 水解生 成得到的; 但我们不排除第一种可能. 与纯 $\mathrm{Ni}(852.8 \mathrm{eV})$ 和 $\mathrm{B}(187.2 \mathrm{eV})$ 的标准结合能相比, Ni-B中单质 $\mathrm{B}$ 的增加 约 $1.4 \mathrm{eV}, \mathrm{Ni}$ 的减小了 $0.7 \mathrm{eV}$, 这表明在 $\mathrm{Ni}-\mathrm{B}$ 中 $\mathrm{B}$ 将部分电 
子供给 $\mathrm{Ni}$, 使得金属 $\mathrm{Ni}$ 为富电子状态, 而 $\mathrm{B}$ 为缺电子态 ${ }^{[23]}$. 采用化学还原法制备不同 $n(\mathrm{Ni}): n(\mathrm{PVP})$ 比的催化剂, 它们在苯酚加氢反应结果见表 1 . 可以看出, 随着 $n(\mathrm{Ni}): n$ (PVP)逐渐增加, 在 $30{ }^{\circ} \mathrm{C}, 0.2 \mathrm{MPa} 反$ 反应 $12 \mathrm{~h}$ 时, 苯酚的转 化率从 $43.2 \%$ 逐渐增加至 $86.2 \%$, 至 $16: 27$ 时又降为 $83.1 \%$, 但环己醇选择性均大于 $99.9 \%$ (表1, 实验 $1-4$ ). 因此, 选择 以 $n(\mathrm{Ni}): n(\mathrm{PVP})=8: 27$ 的 PVP-NiB 催化剂来考察催化剂 的用量、反应时间和温度的影响. 由表1可见随着催化剂 用量的增加, 苯酚的转化率逐渐增加(实验5-7), 当催化 剂用量为 $0.25 \mathrm{~g}$ 时, 升高温度和压力, 反应时间为 $4 \mathrm{~h}$ 时, 转 化率达到 $99.9 \%$ (实验 8 ); 将反应时间延至 18,22 和 $60 \mathrm{~h}$, 苯 酚的转化率均大于 $99.9 \%$, 环己醇选择性仍然大于 $99.9 \%$ (实验9-11); 当温度升至 $60^{\circ} \mathrm{C}$ 反应 $12 \mathrm{~h}$ 或 $100^{\circ} \mathrm{C} 反$ 应 $10 \mathrm{~h}$, 苯酚的转化率均为 $99.9 \%$ (实验 12,13 ); 当将 $\mathrm{H}_{2}$ 压力升至 1.0 和 $2.0 \mathrm{MPa}$, 在 $100{ }^{\circ} \mathrm{C}$ 反应 10 或 $8 \mathrm{~h}$, 苯酚转化率和环己 醇的选择性均大于 $99.9 \%$ (实验 14 和 15 ).

综上可见, PVP-NiB非晶态催化剂对苯酚加氢反应 表现出高催化活性和选择性. 无疑, 这与催化剂的形貌 特征有关. 表征结果显示, 催化剂呈纳米颗粒, 分散均匀, 无团聚现象, 粒径较小; 催化剂中 $\mathrm{Ni}$ 原子和 $\mathrm{B}$ 原子存在明 显的相互作用, 使得 $\mathrm{Ni}$ 呈富电子状态, 而 $\mathrm{B}$ 呈缺电子状态, 这种电子效应极大地提高了催化剂的活性 ${ }^{[23]}$. 该非晶态 合金催化剂具有长程无序, 短程有序的结构特征, 有利于
催化剂对苯酚的吸附, 且具有高度配位不饱和的活性位, 活性位相互间有较强的协同作用, 从而有利于提高表面 $\mathrm{Ni}$ 原子的催化活性 ${ }^{[24]}$.

表2为该催化剂上苯酚衍生物加氢反应结果. 由表 可见, 酚类衍生物加氢活性均低于苯酚, 取代醇类选择性 与苯酚的相似, 在 $120^{\circ} \mathrm{C}$ 和 $1 \mathrm{MPa}$ 下应 $16 \mathrm{~h}$, 对甲基苯酚 和邻甲基苯酚的转化率分别为 $88.3 \%$ 和 $90.1 \%$, 而在 $120^{\circ} \mathrm{C}, 2 \mathrm{MPa}$ 下应 $24 \mathrm{~h}$, 对叔丁基苯酚和愈创木酚的转 化率只有 $20.1 \%$ 和 $20.0 \%$. 苯环上取代基不同, 活性和选 择性明显不同. 活性的降低可能是由于苯环上含有取代 基不同和酚类衍生物在水中的溶解性不同所致, 如对叔 丁基苯酚和愈创木酚的溶解性在水中最小, 相应的转化 率明显低 ${ }^{[7]}$.

总之, 首次将非晶态催化剂PVP-NiB 用于水相苯酚 及其他衍生物加氢反应中, 在低温低压下, 苯酚的转化率 和环己醇的选择性都能够达到 $99.9 \%$. 升高温度, 苯酚的 转化率加快, 环己醇的选择性未发生变化; 将底物拓展 为对甲基苯酚和邻甲基苯酚时, 催化剂显示高活性和高 选择性; 当底物为愈创木酚和对叔丁基苯酚时, 催化效 率比较低, 但是产物取代醇类选择性均达 $99.9 \%$. 因此, 如何提高该催化剂对愈创木酚和对叔丁基苯酚等其它 苯酚衍生物的加氢活性, 以及考察催化剂的循环使用性 能正在进行中. 